\title{
Proteomic Responses during Cold Acclimation in Association with Freezing Tolerance of Velvet Bentgrass
}

\author{
Tatsiana Espevig \\ Arable Crops Division, Norwegian Institute for Agricultural and Environmental Research, Grimstad, \\ Norway 4886
}

Chenping Xu

Texas AgriLife Research Center, Texas A\&M University, Uvalde, TX 78801

Trygve S. Aamlid

Arable Crops Division, Norwegian Institute for Agricultural and Environmental Research, Grimstad, Norway 4886

Michelle DaCosta'
Stockbridge School of Agriculture, University of Massachusetts, Amherst, MA 01003

Bingru Huang ${ }^{1}$

Department of Plant Biology and Pathology, Rutgers University, 59 Dudley Road, New Brunswick, NJ 08901

\begin{abstract}
AdDitional INDEX wORDs. protein, turfgrass, low temperature
Abstract. Cold acclimation improves freezing tolerance in various plants, including perennial grass species. The objectives of this study were to determine protein changes in crowns of velvet bentgrass (Agrostis canina) during cold acclimation in association with freezing tolerance. Treatments consisted of: 1) nonacclimated (NA) plants maintained at $18 / 12{ }^{\circ} \mathrm{C}$ (day/night); 2) plants acclimated at a constant $2^{\circ} \mathrm{C}$ for 4 weeks with a 10 -hour photoperiod [A4 (cold acclimation)]; and 3) plants acclimated at a constant $2^{\circ} \mathrm{C}$ for 4 weeks with additional subzero acclimation (SZA) at a constant $-2{ }^{\circ} \mathrm{C}$ for 2 weeks (A4 + SZA2). Exposing plants to A4 significantly increased freezing tolerance, but additional SZA had no further beneficial effects on freezing tolerance, as demonstrated by the lethal temperature for $\mathbf{5 0} \%$ of the test population $\left(\mathbf{L T}_{\mathbf{5 0}}\right)$. Thirteen protein spots with increased abundance (up-regulated) or with decreased abundance (down-regulated) during cold acclimation were identified for biological functions. Proteins up-regulated after cold acclimation (A4 or A4 + SZA2) included methionine synthase, serine hydroxymethyltransferase, aconitase, UDP-D-glucuronate decarboxylase, and putative glycine-rich protein. Cold acclimation-responsive proteins involved in amino acid metabolism, energy production, stress defense, and secondary metabolism could contribute to the improved freezing tolerance induced by cold acclimation in velvet bentgrass.
\end{abstract}

Winter injury in field environments is a common problem for perennial grass species used as forage or turf in cool climatic regions. Winter injury may be caused by different stresses such as the duration and magnitude of low temperature exposure, lack of oxygen resulting from ice encasement, and/or susceptibility to low-temperature fungal diseases (Bertrand et al., 2003, 2011; Humphreys and Eagles, 1988). Although specific resistance mechanisms may vary among these different stresses, it has been demonstrated that acquisition of freezing tolerance is a major component of winterhardiness of perennial

\footnotetext{
Received for publication 6 June 2012. Accepted for publication 14 Aug. 2012. This study was conducted as a collaborative project among the Norwegian Institute of Agricultural and Environmental Research (Bioforsk), the Norwegian University of Life Science, Rutgers University, and the University of Massachusetts. We thank the Scandinavian Turfgrass and Environment Research Foundation, the Norwegian Research Council, and the Rutgers Center for Turfgrass Science for funding support. We are also grateful to Dr. J. Scott Ebdon for assistance with $\mathrm{LT}_{50}$ estimations. Thanks go to Dr. Emily Merewitz, Patrick Burgess, and David Jespersen for critical review of the article.

${ }^{1}$ Corresponding authors. E-mail: mdacosta@psis.umass.edu, huang@AESOP.
} Rutgers.edu. grasses (Hulke et al., 2008; Humphreys and Eagles, 1988; Xiong and Fei, 2006).

Freezing tolerance is dependent on a period of acclimation to low temperatures that alter various metabolic processes to physiologically precondition plants for subsequent freezing stress (Guy, 1999; Thomashow, 1999). Two consecutive stages of cold acclimation have been suggested in winter cereals and temperate grass species (Tumanov, 1940). The first acclimation phase occurs at temperatures above freezing $\left(\approx 2\right.$ to $\left.5{ }^{\circ} \mathrm{C}\right)$ and contributes to accumulation of cryoprotectants, including antifreeze proteins, reserve carbohydrates, and alterations in phospholipid and fatty acid composition, which enhance cellular stability when freezing occurs (Dionne et al., 2001a, 2001b; Guy, 1999; Hoffman et al., 2010; Livingston, 1991; Rajashekar, 2006; Thomashow, 1999; Tronsmo et al., 1993). The second phase of acclimation occurs at temperatures below freezing $\left(-2\right.$ to $\left.-5{ }^{\circ} \mathrm{C}\right)$. It is commonly referred to as SZA and leads to acquisition of additional freezing tolerance in some plant species, including perennial grasses (Herman et al., 2006; Livingston, 1996; Tumanov, 1940). Exposure to subfreezing temperatures is commonly associated with ice formation in the 
apoplast and dehydration of plant cells (Steponkus and Lynch, 1989). The high intracellular concentration of solutes helps to reduce significant loss of intracellular water and prevent ice formation inside cells (Herman et al., 2006). For winter wheat (Triticum aestivum), the completion of SZA occurred within a shorter period of time compared with acclimation at abovefreezing temperatures (Tumanov, 1940). Herman et al. (2006) also demonstrated that morphological changes in crowns of winter wheat occurred within a few hours of exposure to SZA, whereas maximal acclimation was achieved after $3 \mathrm{~d}$ of SZA. In general, experimental evidence regarding structural, biochemical, and metabolic changes during SZA in winter cereals is restricted to few studies (Herman et al., 2006; Livingston, 1996), and little is known in general regarding mechanisms of SZA in perennial grasses.

Mechanisms underlying cold acclimation in perennial grasses can be revealed using novel genomic and proteomics approaches. The identification of cold-regulated (COR) proteins may provide additional information about numerous metabolic processes and their activities under cold acclimation. Changes in COR proteins have been observed in response to decreasing temperatures, including late embryogenesis abundant (LEA) proteins, antifreeze proteins (AFP), heat-shock proteins, detoxification enzymes, and ice recrystallization inhibition proteins (Close et al., 1989; Griffith and Yaish, 2004; Guy, 1999; Janská et al., 2010; Sandve et al., 2008; Zhang et al., 2010). Many of these proteins function in direct protection from freezing-induced cellular dehydration and mechanical damage. For example, the specific family of LEA proteins known as dehydrins have been widely reported to function as chaperones to help stabilize membranes and proteins under conditions of dehydration, including cold and drought (Close, 1996). In addition, AFP have been reported to adhere and inhibit the growth of ice crystals (Duman and Olsen, 1993; Griffith et al., 1997), inhibit ice recrystallization (Sandve et al., 2008), and protect thylakoid membranes against freeze-thaw damage (Sieg et al., 1996).

The synthesis and expression of specific COR proteins during cold acclimation may vary according to plant species or genotype such that certain proteins differentially accumulate between freezing-tolerant and freezing-sensitive plants (Dionne et al., 2001b; Patton et al., 2007; Perras and Sarhan, 1989; Puhakainen et al., 2004). For example, Kosmala et al. (2009) found that 41 proteins were differentially accumulated between freezing-tolerant and freezing-sensitive meadow fescue (Festuca pratensis) plants with differences in protein abundance detected as early as $2 \mathrm{~d}$ of cold acclimation at $4{ }^{\circ} \mathrm{C}$. In addition, the abundance of COR proteins has also been shown to vary based on exposure to different temperatures and durations of cold acclimation (Amme et al., 2006; Bocian et al., 2011; Kosmala et al., 2009). In a study evaluating winter wheat at different stages of cold acclimation, Herman et al. (2006) identified significant changes in protein abundance (either increased and decreased abundance) when plants were shifted from a cold acclimation regime of $3{ }^{\circ} \mathrm{C}$ to a SZA regime of $-3{ }^{\circ} \mathrm{C}$. To date, this is one of the few published studies on the proteomic effects of SZA in relation to freezing tolerance of plants. Therefore, additional research is needed to understand how the regulation of specific proteins may be involved at different stages of cold acclimation, including SZA, and contribute to improved freezing tolerance in perennial grass species.
Among perennial grasses used as turf, Agrostis species demonstrate better winter survival capacity compared with other turfgrasses (Aamlid et al., 2006; Tompkins et al., 2000). In an evaluation of cool-season grasses under controlled freezing conditions, Gusta et al. (1980) reported that creeping bentgrass (Agrostis stolonifera) was the most freezing-tolerant, surviving temperatures below $-30{ }^{\circ} \mathrm{C}$, whereas kentucky bluegrass (Poa pratensis) and perennial ryegrass (Lolium perenne) exhibited significantly higher killing temperatures ( -21 to $-30{ }^{\circ} \mathrm{C}$ and -5 to $-15^{\circ} \mathrm{C}$, respectively). Recent studies have also demonstrated potential differences in winter survival capacity among different Agrostis species. In cultivar evaluation trials at two locations in Norway from 2003 to 2006, velvet bentgrass was found to exhibit better winter survival and turf quality characteristics compared with creeping bentgrass (Aamlid et al., 2006; Molteberg et al., 2008). Based on appropriate cultivar selection, there is also evidence to suggest the potential use of velvet bentgrass as an alternative Agrostis species for reduced input environments (Brilman, 2003; Chakraborty et al., 2006; DaCosta and Huang, 2006; Koeritz and Stier, 2009). As a result of potential expanded use of this winter-hardy species in northern climates, additional information is required to understand the metabolic processes involved in cold acclimation and freezing tolerance of velvet bentgrass. Therefore, the objectives of our study were to determine protein changes in response to different stages of cold acclimation and to identify specific proteins associated with freezing tolerance of velvet bentgrass.

\section{Materials and Methods}

Plant material and growing conditions. Detailed information regarding plant material and experimental procedures was described previously (Espevig et al., 2011). Briefly, mature sods of 'Greenwich' velvet bentgrass were taken from field plots at Rutgers University (North Brunswick, NJ) and transplanted into polyvinyl chloride tubes filled with sand. Plants were maintained in a growth chamber at $18 / 12^{\circ} \mathrm{C}$ (day/ night temperatures) with a $16-\mathrm{h}$ photoperiod and photosynthetic photon flux $(P P F)$ of $500 \mu \mathrm{mol} \cdot \mathrm{m}^{-2} \cdot \mathrm{s}^{-1}$ for 5 weeks. Plants were irrigated daily, hand-clipped to $3-\mathrm{mm}$ height three times per week, and fertilized once per week with $100 \mathrm{~mL}$ of a complete Hoagland's nutrient solution (Hoagland and Arnon, 1950).

Acclimation treatments. The experiment consisted of three treatments: 1) NA plants maintained at $18 / 12{ }^{\circ} \mathrm{C}$ (day/night) with a 10-h photoperiod and $P P F$ of $500 \mu \mathrm{mol} \cdot \mathrm{m}^{-2} \cdot \mathrm{s}^{-1}$; 2) plants acclimated at a constant $2{ }^{\circ} \mathrm{C}$ for 4 weeks with a 10 -h photoperiod and $P P F$ of $250 \mu \mathrm{mol} \cdot \mathrm{m}^{-2} \cdot \mathrm{s}^{-1}$ (A4); and 3) plants acclimated at a constant $2{ }^{\circ} \mathrm{C}$ for 4 weeks with an additional SZA at a constant $-2{ }^{\circ} \mathrm{C}$ for 2 weeks (A4 + SZA2). Because it has previously been shown that there is no light requirement for SZA (Le et al., 2008), this acclimation treatment was conducted in darkness. The durations of the acclimation treatments were selected based on previous studies and reported to be sufficient to induce freezing tolerance in grasses (Dionne et al., 2001a, 2001b; Hoffman et al., 2010). After each acclimation treatment, plants were harvested for freeze tests and protein analyses as described subsequently.

Determination of Freezing tolerance. After each acclimation treatment, intact plants with leaves and roots were used for determination of freezing tolerance based on whole plant survival. Plants exposed to SZA were thawed overnight at $4{ }^{\circ} \mathrm{C}$ to facilitate sampling as described by Dionne et al. (2001a). For 
each test temperature, 10 groups of plants (four to five plants per group) were washed free of soil, wrapped in a moistened paper towel to ensure ice nucleation, and placed into a freezer bag according to the methods previously described by Espevig et al. (2011). Four replicates were used for each test temperature. During harvest, the bags were temporarily stored at $4{ }^{\circ} \mathrm{C}$ until all plant material had been sampled. Freezing tests were conducted using a programmable freeze chamber (ScienTemp Corp., Adrian, MI). The freezer was cooled in a stepwise fashion at a rate of $2{ }^{\circ} \mathrm{C} \cdot \mathrm{h}^{-1}$ to the desired temperature and held at the each test temperature $\left(4,-6,-9,-12,-15,-18\right.$, and $\left.-21^{\circ} \mathrm{C}\right)$ for $2 \mathrm{~h}$. Bags were removed from the freezer after each test temperature and thawed at $4{ }^{\circ} \mathrm{C}$ for a minimum of $12 \mathrm{~h}$.

After thawing, tillers were re-planted into cell trays filled with a commercial potting medium of Pro-Mix (Premier Horticulture, Québec, Canada) and placed in a greenhouse at $\approx 20{ }^{\circ} \mathrm{C}$. Recovery was assessed after a 3-week regrowth period and percent whole plant survival (WPS) was calculated as: WPS $=$ (number of plants survived/total number of plants $) \times$ 100. The lethal temperature for $50 \%$ of the test population $\left(\mathrm{LT}_{50}\right)$ was determined mathematically by curve fitting percent survival to temperature using a four-parameter sigmoid model (Sigma Plot Version 4.0; Systat Software, Chicago, IL) as previously described by Ebdon et al. (2002).

Proteomic anAlysis. After each acclimation treatment, $\approx 0.5 \mathrm{~g}$ (fresh weight) of crown tissues (including stem bases) were harvested from each of three replicates, immediately frozen in liquid nitrogen, and stored at $-80^{\circ} \mathrm{C}$ for protein analysis. Plant crown tissues used for proteomic analysis were separate from those whole plants used for whole-plant survival assessment $\left(\mathrm{LT}_{50}\right)$ but were collected from the same pots (replicates).

Protein extraction was performed according to the trichloracetic acid (TCA)/acetone method described by $\mathrm{Xu}$ et al. (2008). Briefly, crowns were homogenized with liquid nitrogen and incubated with $10 \mathrm{~mL}$ of precipitation solution $(10 \% \mathrm{TCA}$ and $0.07 \%$ 2-mercaptoethanol in acetone) overnight at $-20{ }^{\circ} \mathrm{C}$. The solution was centrifuged at $10,062 \mathrm{~g}_{\mathrm{n}}$ for $15 \mathrm{~min}$ at $4{ }^{\circ} \mathrm{C}$, the pellets were rinsed twice with ice-cold $0.07 \%$ 2-mercaptoethanol in acetone to remove pigments and lipids, then vacuum-dried, resuspended in rehydration solution $\{8 \mathrm{M}$ urea, $2 \mathrm{M}$ thiurea, $2 \%$ 3 [(3-cholamidopropyl) dimethylammonio]-1-propane sulfonate (CHAPS), 1\% dithiothreitol (DTT), and 1\% pharmalyte $\}$, and sonicated to provide transition of proteins from the pellet to the solution. The solution was then centrifuged at 10,062 $\mathrm{g}_{\mathrm{n}}$ for $15 \mathrm{~min}$ at $4{ }^{\circ} \mathrm{C}$, the supernatants were removed, and protein concentrations were determined according to Bradford (1976) using a commercial dye reagent (Bio-Rad Laboratories, Hercules, CA) with bovine serum albumen as a standard.

First-dimension [isoelectric focusing (IEF)] and seconddimension [sodium dodecyl sulphate-polyacrylamide gel electrophoresis (SDS-PAGE)] separation of proteins were performed according to a procedure described by Xu et al. (2008). Briefly, immobilized $\mathrm{pH}$ gradient (IPG) strips ( $\mathrm{pH}$ 3.0-10.0, linear gradient, $13 \mathrm{~cm}$ ) were filled with $250 \mu \mathrm{L}$ rehydration buffer (8 M urea, $2 \mathrm{M}$ thiourea, 2\% CHAPS, 1\% DTT, 1\% pharmalyte, and $0.002 \%$ bromophenol blue) containing $200 \mu \mathrm{g}$ of proteins and rehydrated at room temperature in IPGPhor apparatus (GE Healthcare, Piscataway, NJ) at $50 \mathrm{~V}$ for $12 \mathrm{~h}$. After IEF for a total $94.5 \mathrm{kVh}$, IPG strips were denatured with $10 \mathrm{~mL}$ of equilibration buffer (50 m tris- $\mathrm{HCl} \mathrm{pH} 8.8,6 \mathrm{M}$ urea, 30\% glycerol, 2\% sodium dodecyl sulphate, and $0.002 \%$ bromophenol blue) containing 1\% DTT for $20 \mathrm{~min}$. Then the strips were incubated twice with $10 \mathrm{~mL}$ of the same buffer containing $2.5 \%$ iodoacetamide for $15 \mathrm{~min}$. The second-dimension electrophoresis was performed on $12.5 \%$ SDS-polyacrylamide gel using an electrophoresis unit (Hoefer SE 600 Ruby; GE Healthcare). The gels were stained with Coomassie brilliant blue-250 (Newsholme et al., 2000) and scanned using a Personal Densitometer (GE Healthcare). Protein abundance was the normalized spot volume (area $\times$ intensity) on scanned protein gels using Progenesis Same Spots software (Nonlinear Dynamics, Durham, NC). Data were subjected to analysis of variance to test the effects of acclimation treatment. Significant differences in protein abundance between acclimation treatments were separated by Fisher's least significant difference (LSD) test at the $0.05 P$ level.

Protein digestion and identification were performed as described previously ( $\mathrm{Xu}$ et al., 2008). The gel spots were excised and washed with $30 \%$ acetonitrile in $50 \mathrm{~mm}$ ammonium bicarbonate before DTT reduction and iodoacetamide alkylation. Trypsin was used for digestion at $37{ }^{\circ} \mathrm{C}$ overnight. The resulting peptides were extracted with $30 \mu \mathrm{L}$ of $1 \%$ trifluoroacetic acid followed by $\mathrm{C}_{18}$ Zip Tip (Millipore, Billerica, MA) desalting. For the mass spectrometry (MS) analysis, the peptides were mixed with $7 \mathrm{mg} \cdot \mathrm{mL}^{-1} \alpha$-cyano-4-hydroxy-cinnamic acid matrix in a 1:1 ratio and spotted onto a matrix-assisted laser desorption/ionization (MALDI) plate. The peptides were analyzed on a 4800 MALDI time-of-flight (TOF)/TOF analyzer (Applied Biosystems, Framingham, MA). Mass spectra (MS; $m / z$ 880-3200) were acquired in positive ion reflector mode. For subsequent MS/MS sequencing analysis in $1 \mathrm{kV}$ mode, 25 mostintense ions were selected. Protein identification was performed by searching the combined MS and MS/MS spectra against the green plant NCBI nonredundant protein sequence database using a local MASCOT search engine (Version 1.9; Matrix Science, London, U.K.) on a Global Proteome Server (Version 3.5; Applied Biosystems). A protein containing at least two unique peptides with confidence interval values no less than $95 \%$ was considered being identified.

EXPERIMENTAL DESIGN AND STATISTICAL ANALYSES. The experimental design was completely randomized with three treatments and four replicates per treatment (pots) for freezing tolerance determination ( $\mathrm{LT}_{50}$ based on whole plant survival) and three replicates per treatment (pots) for protein analysis. Analysis of variance for $\mathrm{LT}_{50}$ was performed using the software packages STATISTICA (Version 6.0; StatSoft, Tusla, OK) (Hill and Lewicki, 2007). Significant differences among treatments were identified by Fisher's LSD test at the $0.05 P$ level.

\section{Results and Discussion}

Acclimation of plants for 4 weeks at $2{ }^{\circ} \mathrm{C}$ resulted in an increase in freezing tolerance, as determined using $\mathrm{LT}_{50}$ assessments, which consisted of $-14.5^{\circ} \mathrm{C}$ for $\mathrm{A} 4$ and $-8.6^{\circ} \mathrm{C}$ for NA (Table 1). In some studies with annual crops and grass species, SZA was shown to improve freezing tolerance compared with acclimation at low, above-freezing temperatures only (Dionne et al., 2001a; Herman et al., 2006; Livingston, 1996; Tumanov, 1940). However, in our study, additional SZA did not result in enhanced freezing tolerance because the $\mathrm{LT}_{50}$ of plants exposed to A4 and A4 + SZA2 was not significantly different. As previously discussed by Espevig et al. (2011), the lack of additional benefits with SZA on freezing tolerance in our study could be the result of the long duration ( 4 weeks) of the cold acclimation period before the subzero temperature treatment. 
The sufficiency of artificial acclimation effects on freezing tolerance may depend on plant species and temperature (Huner et al., 1993; Tepperman et al., 2001) as well as the duration of SZA (Herman et al., 2006; Vágújfalvi et al., 1999; Veisz and Sutka, 1989). Vágújfalvi et al. (1999) and Veisz and Sutka (1989) reported a negative effect of prolonged period of cold acclimation at $2{ }^{\circ} \mathrm{C}$ (from 7 to 8 weeks or from 5 to 6 weeks) on freezing tolerance in wheat. In addition, Herman et al. (2006) reported a negative effect of prolonged SZA on winter wheat survival when crowns were maintained at $-3{ }^{\circ} \mathrm{C}$ for periods longer than $3 \mathrm{~d}$. In contrast, Dionne et al. (2001a) reported that prolonged SZA at $-2{ }^{\circ} \mathrm{C}$ for 2 weeks improved freezing tolerance of annual bluegrass (Poа аппиа) relative to plants acclimated at $2{ }^{\circ} \mathrm{C}$. Differences between our study and that of Dionne et al. (2001a) may be the result of interspecific differences in freezing tolerance, because velvet bentgrass and other Agrostis species exhibit greater winterhardiness compared with annual bluegrass (Aamlid et al., 2006; Tompkins et al., 2000). However, additional research is necessary to examine the effects of artificial SZA on changes in freezing tolerance compared with that encountered under natural field conditions.

Currently, there are very few reports on protein changes in crown tissues in grasses in response to cold acclimation. In this study, among 375 separated protein spots from crown tissues in velvet bentgrass (Fig. 1), $\approx 86$ spots exhibited response to at least one acclimation treatment. Nineteen protein spots that were differentially expressed among NA, A4, and A4 + SZA2 plants were identified using mass spectrometry. Among them, 13 spots were identified with putative biological functions and six spots with unknown functions. The abundance level of the six unknown proteins is shown in Figure 2. Spots 14, 15, 16, 17, and 18 exhibited accumulation under both A4 and A4 + SZA2 treatments. Spot 19 had increased abundance at A4 + SZA2 treatment but did not change at A4 treatment compared with the non-acclimated treatment. Because the functions of these proteins were unknown, their involvement in cold acclimation and freezing tolerance could not be further discussed. The 13 identified proteins were divided into four functional categories described by Bevan et al. (1998), including metabolism, energy, stress defense, and secondary metabolism (Table 2). The association of these proteins with cold acclimation-induced freezing tolerance is discussed subsequently based on their biological functions. There were two proteins with two or more spots with different pI and molecular weight (methionine synthase and cytosolic glyceraldehyde-3-phosphate dehydrogenase). Multiple spots for a single protein are commonly found on two-dimensional (2D) gels (Giavalisco et al., 2005; Sarnighausen et al., 2004). Several factors may be responsible for this phenomenon. The migration of proteins on a 2D-PAGE gel is very sensitive to small structural differences. These spots might be different isoforms derived from different genes of a multigene family. The complex genome of velvet bentgrass is expected to contain multiple copies of many genes, and the distinct biophysical properties might be the result of amino acid sequence differences in the different isoforms. Alternatively, one gene product may undergo different co- and/or post-translational modifications that affect its $\mathrm{pI}$ and/or molecular weight.

Metabolism. The proteins associated with metabolism that exhibited significant responses to cold acclimation treatments included methionine synthase (spots 1-3) and serine hydroxymethyltransferase (spot 4 ) (Table 2). The
Table 1. Effect of cold acclimation on freezing tolerance of velvet bentgrass expressed as mean lethal temperatures for $50 \%$ of test population $\left(\mathrm{LT}_{50}\right)$.

\begin{tabular}{lc}
\hline Acclimation treatment & $\mathrm{LT}_{50}\left({ }^{\circ} \mathrm{C}\right)$ \\
\hline NA & $-8.6 \mathrm{~b}^{\mathrm{z}}$ \\
$\mathrm{A} 4$ & $-14.8 \mathrm{a}$ \\
$\mathrm{A} 4+\mathrm{SZA} 2$ & $-14.7 \mathrm{a}$ \\
$P$ & $<0.001$
\end{tabular}

$\overline{{ }^{z}}$ The same letter indicates no significant difference among treatments based on Fisher's protected least significant difference test.

$\mathrm{NA}=$ nonacclimated plants maintained at $18 / 12{ }^{\circ} \mathrm{C}$ (day/night); $\mathrm{A} 4=$ plants acclimated at a constant $2{ }^{\circ} \mathrm{C}$ for 4 weeks; $\mathrm{A} 4+\mathrm{SZA} 2=$ plants acclimated at a constant $2{ }^{\circ} \mathrm{C}$ for 4 weeks with an additional subzero acclimation at a constant $-2{ }^{\circ} \mathrm{C}$ for 2 weeks.

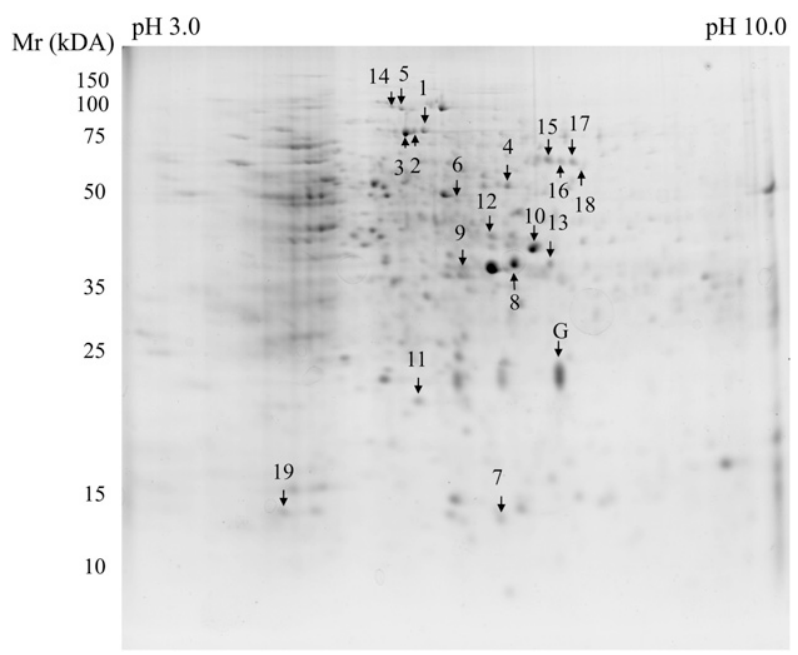

Fig. 1. Coomassie-stained two-dimensional polyacrylamide gel electrophoresis (2D-PAGE) gel of separated proteins from crowns of velvet bentgrass acclimated at $2{ }^{\circ} \mathrm{C}$ for 4 weeks followed by subzero acclimation at $-2{ }^{\circ} \mathrm{C}$ for 2 weeks. The numbered spots were affected by acclimation treatments. Germin $(\mathrm{G})$ was identified but was not regulated by acclimation.

abundance of both proteins increased in response to A4 or A4 + SZA2 treatments, but these proteins did not exhibit significant differences in the abundance level between the two acclimation treatments.

Quantitative changes in amino acids in plants in response to cold acclimation have been previously reported, but their specific role in freezing tolerance remains unclear (Bertrand et al., 2011; Dionne et al., 2001b; Naidu et al., 1991). In addition to possible direct roles in conferring freezing tolerance, increased availability of specific amino acids may serve as nitrogen reserves to improve overwintering capacity and spring regrowth of plants (Volenec et al., 1996) and also serve as precursors for defense compounds involved in resistance to low temperature fungi (Bertrand et al., 2011).

In our study, the increased abundance of both serine hydroxymethyltransferase and methionine synthase in response to cold acclimation suggested a cold-induced increase or activation of amino acid metabolism. The major reaction catalyzed by serine hydroxymethyltransferase is the interconversion of serine and glycine, resulting in generation of onecarbon units for the biosynthesis of many organic compounds including methionine, nucleotides, thymidylate, and choline 

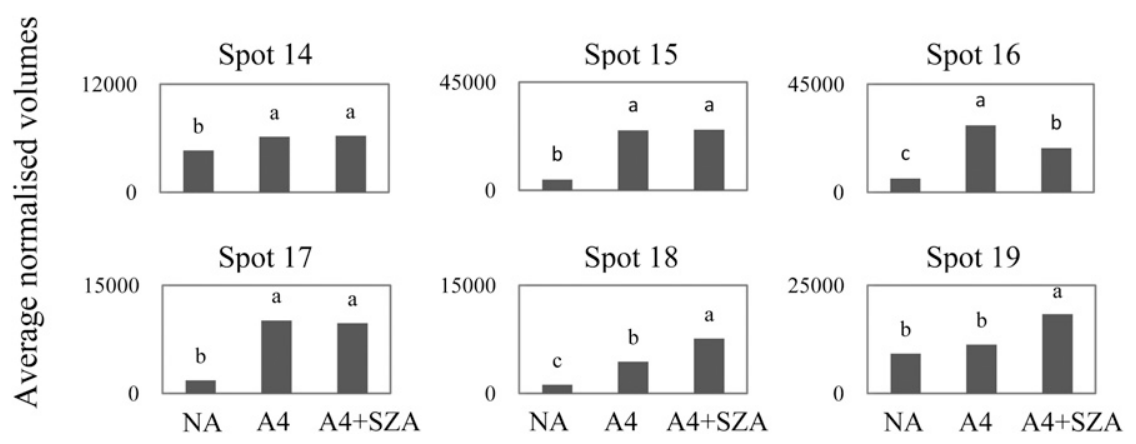

Fig. 2. The relative abundance of unidentified cold-regulated proteins from crowns of velvet bentgrass: $\mathrm{NA}=$ nonacclimated plants maintained at $18 / 12^{\circ} \mathrm{C}$ (day/night); $\mathrm{A} 4=$ plants acclimated at a constant $2{ }^{\circ} \mathrm{C}$ for 4 weeks; A4 + SZA2 $=$ plants acclimated at a constant $2{ }^{\circ} \mathrm{C}$ for 4 weeks with an additional subzero acclimation at a constant $-2{ }^{\circ} \mathrm{C}$ for 2 weeks. Columns followed by same letter indicate no significant difference based on Fisher's protected least significant difference test.

(Schirch and Szebenyi, 2005). Increased availability of glycine would also be essential for glutathione synthesis. Glutathione has been shown to increase in plants in response to low temperature and is thought to play a key role in the reduction of hydrogen peroxide concentration in plants during cold acclimation (Kocsy et al., 2001). In other studies, serine hydroxymethyltransferase was also shown to be induced in response to cold treatment in leaves of arabidopsis [Arabidopsis thaliana (Byun et al., 2009)] and sunflower [Helianthus annuus (Balbuena et al., 2011)] and was reported to play a role in protecting plants from oxidative stress in rice (Oryza sativa) during drought (Ali and Komatsu, 2006). The induction of methionine synthase in response to low temperature has been reported in other plant species (Machida et al., 2008; Renaut et al., 2009; Rorat et al., 1997). Methionine synthase catalyzes the terminal step of methionine biosynthesis, which then serves as an important starting point in the biosynthesis of important metabolites including polyamines and ethylene (Ravanel et al., 1998; Wang et al., 2002). In general, polyamines are reported to play an important role in stabilization of lipids and proteins as well as cell signaling and regulation of plant hormones including abscisic acid (Alcázar et al., 2010; Kramer and Wang, 1990). An increase in polyamine synthesis has been observed in response to cold acclimation for several plant species with an increase in freezing tolerance associated with an increase in key polyamines such as putrescine, spermidine, and spermine (Alcázar et al., 2011). Ethylene was reported to increase protein production in the apoplast and induce antifreeze activity in nonacclimated winter ryegrass [Lolium multiflorum ( $\mathrm{Yu}$ et al., 2001)]. Therefore, the increase in the abundance of serine hydroxymethyltransferase and methionine synthase could contribute to cold acclimation-induced freezing tolerance, which may be related to the involvement in synthesis of amino acids, polyamines, ethylene, and other metabolites with important roles in stress tolerance and improving overwintering capacity of plants.

ENERGY. Some proteins in this category showed differential responses to the two acclimation treatments (Table 2). The abundance of aconitase (spot 5) increased significantly under both cold acclimation treatments compared with the nonacclimated control but did not differ between the two acclimation treatments. The abundance of ribulose-1,5-bisphosphate carboxylase/oxygenase (Rubisco) large and small subunits (spots 6 and 7, respectively) and glyceraldehydes-3-phosphate dehydrogenase (spots 8 and 9) decreased significantly in response to A4 or A4 + SZA2 treatment but was not significantly different between the two acclimation treatments. Fructose-bisphosphate aldolase (spot 10) exhibited a significant decline in its abundance in response to the $\mathrm{A} 4+\mathrm{SZA} 2$ treatment but did not change during the A4 treatment. The abundance of fructose-bisphosphate aldolase was significantly higher in A4 treatment than A4 + SZA2 treatment.

Because photosynthesis and respiration are temperature-dependent processes (Guy, 1999; Huner et al., 1993; Klimov, 2009), significant changes in enzymes and other proteins involved in carbon metabolism in response to cold acclimation have been reported (Herman et al., 2006; Kosmala et al., 2009; Rapacz et al., 2008). Kosmala et al. (2009) showed that significant changes in leaf proteins of meadow fescue occurred within $2 \mathrm{~d}$ after exposure of plants to cold acclimation, and most of the regulated proteins were involved in photosynthesis. In the current study, we found significant downregulation of Rubisco large and small subunits in response to cold acclimation. Similarly, Herman et al. (2006) reported down-regulation of Rubisco in leaves of winter wheat. Hahn and Walbot (1989) also showed $\approx 90 \%$ reduction in the synthesis for the small Rubisco subunit and $80 \%$ for the large Rubisco subunit in leaves of rice.

Fructose-bisphosphate aldolase was down-regulated only after SZA in our study. The metabolic function of cytosolic fructose-bisphosphate aldolase is cleavage of fructose 1,6-bisphosphate (F-1,6-BP) into glyceraldehyde 3-phosphate and dihydroxyacetone phosphate during glycolysis. In addition, cytosolic glyceraldehyde-3-phosphate dehydrogenase, which catalyzes the subsequent conversion of glyceraldehyde 3-phosphate to glycerate 1,3-bisphosphate, was down-regulated in response to $\mathrm{A} 4$. Taken together, the data suggest that adaptation of velvet bentgrass to prolonged cold acclimation involved a down-regulation of respiration, which could reduce the potential for metabolism of cryoprotective solutes and improve overwintering capacity. In a previous study, winter wheat cultivars exhibiting lower respiration rates and carbohydrate consumption during winter months had significantly improved survival compared with cultivars with higher rates of winter respiration (Sagisaka et al., 1991). Lower winter respiration rates have also been associated with improved winter survival for timothy [Phleum pratense (Bertrand et al., 2003)].

There is limited information regarding the physiological role of cytoplasmic aconitase in plants. The enzyme appears to be involved in the glyoxylate cycle (Courtois-Verniquet and Douce, 1993), which converts lipid to sucrose. Mitochondrial aconitase catalyzes the isomerization of citrate to isocitrate in the tricarboxylic acid cycle (Verniquet et al., 1991). A more recent study by Moeder et al. (2007) demonstrated a possible role for aconitase in mediating plant responses to oxidative stress. Thus, additional research is necessary to understand how the up-regulation of aconitase could be associated with conferring freezing tolerance in grasses.

STress Defense. Two proteins involved in stress defense were found to be responsive to cold acclimation treatments (Table 2). A putative glycine-rich protein (spot 11) exhibited an 
Table 2. Relative abundance of cold-regulated proteins from crowns of velvet bentgrass divided into functional groups according to the classification in Bevan et al. (1998).

\begin{tabular}{|c|c|c|c|c|c|c|}
\hline Spot no. & Protein name (species) & Accession & $\begin{array}{c}\text { Protein } \\
\text { molecular } \\
\text { wt }(\mathrm{kDA})\end{array}$ & $\begin{array}{c}\text { Protein } \\
\text { isoelectric } \\
\text { point }\end{array}$ & \multicolumn{2}{|c|}{ Avg normalized values ${ }^{\mathrm{z}}$} \\
\hline & & & & & NA A & A4 A4 \\
\hline 1 & Methionine synthase (Hordeum vulgare) & gi $\mid 8134570$ & 84.8 & 6.1 & 15000 & \\
\hline 2 & Methionine synthase (H. vulgare) & gi| 8134570 & 84.8 & 6.10 & 15000 & $\stackrel{b}{a}$ \\
\hline 3 & Methionine synthase (H. vulgare) & gi|50897038 & 84.5 & 5.68 & 50000 & \\
\hline 4 & $\begin{array}{l}\text { Serine hydroxymethyl-transferase } \\
\quad \text { (Arabidopsis thaliana) }\end{array}$ & gi| 11762130 & 51.8 & 7.12 & 15000 & \\
\hline 5 & Aconitase (Lycopersicon pennellii) & gi|29027432 & 98.1 & 6.07 & 15000 & \\
\hline 6 & $\begin{array}{l}\text { Ribulose-1,5-bisphosphate carboxylase/oxygenase } \\
\text { (Rubisco) large subunit (Agrostis capillaries) }\end{array}$ & gi|41056380 & 51.8 & 6.13 & 50000 & \\
\hline 7 & Rubisco small subunit (Avena clauda) & gi|6573202 & 18.8 & 8.60 & 50000 & \\
\hline 8 & $\begin{array}{l}\text { Glyceraldehyde-3-phosphate dehydrogenase, } \\
\text { cytosolic (Oryza sativa ssp. indica) }\end{array}$ & gi|120680 & 36.5 & 6.67 & 170000 & \\
\hline 9 & $\begin{array}{l}\text { Glyceraldehyde-3-phosphate dehydrogenase } \\
\text { cytosolic }(O . \text { sativa ssp. indica) }\end{array}$ & gi|120668 & 33.2 & 6.20 & 50000 & \\
\hline 10 & $\begin{array}{l}\text { Fructose-bisphosphate aldolase, cytosolic } \\
\quad(\text { O. sativa ssp. japonica })\end{array}$ & gi|218157 & 38.7 & 6.56 & 70000 & \\
\hline 11 & Putative glycine-rich protein (Triticum aestivum) & gi|40363759 & 19.2 & 5.63 & 25000 & \\
\hline 12 & Putative peroxidase (O. sativa ssp. japonica) & gi|115436084 & 37.9 & 6.46 & 25000 & \\
\hline 13 & UDP-D-glucuronate decarboxylase (H. vulgare) & gi|50659026 & 38.9 & 7.10 & 30000 & \\
\hline
\end{tabular}

${ }^{\mathrm{z}} \mathrm{NA}=$ nonacclimated plants maintained at $18 / 12{ }^{\circ} \mathrm{C}$ (day/night); $\mathrm{A} 4=$ plants acclimated at a constant $2{ }^{\circ} \mathrm{C}$ for 4 weeks; A4 $+\mathrm{SZA} 2=$ plants acclimated at a constant $2^{\circ} \mathrm{C}$ for 4 weeks with an additional subzero acclimation at a constant $-2{ }^{\circ} \mathrm{C}$ for 2 weeks. Columns in each graph followed by same letter indicate no significant difference based on Fisher's protected least significant difference test.

increase in abundance after A4 treatment but then decreased back to similar levels as the non-acclimated control in response to A4 + SZA2 treatment. The abundance of a putative peroxidase (spot 12) was significantly lower in response to both A4 or A4 + SZA2 compared with NA but were not significantly different between the two acclimation treatments.

The generation of $\mathrm{H}_{2} \mathrm{O}_{2}$ or other reactive oxygen species (ROS) is commonly associated with abiotic and biotic stress conditions (Neill et al., 2002). According to the current understanding of the mechanisms underlying cold acclimation in plants, the generation of ROS may arise from imbalances in metabolic reactions associated with processes such as photosynthesis and respiration (Huner et al., 1993, 1998; Mittler et al., 2004). As a result, plants produce enzymatic and nonenzymatic antioxidants to regulate levels of ROS and mitigate oxidative stress in plant tissues. Although an up-regulation of peroxidase might be expected to confer better freezing tolerance capacity, we found down-regulation of this protein in crowns of velvet bentgrass in response to A4 and A4 + SZA2 . Baek and Skinner (2003) also reported a decline in gene expression levels of specific antioxidants over a 4-week cold acclimation period, whereas gene expression levels of several other antioxidants were significantly enhanced during this period. Although there are a large number of antioxidant enzymes and compounds involved in regulation of ROSgenerating pathways of plants, only one putative peroxidase was identified in our study. Therefore, additional proteomic analyses will be necessary to better understand the regulation of oxidative stress during the acquisition of freezing tolerance in grasses.

A putative glycine-rich protein was up-regulated in response to cold acclimation, but its production was found to return to the same level as in non-acclimated plants after SZA. This protein had two-sequence similarity with cold shock protein (CSP) from wheat (Karlson et al., 2002). Plant CSPs with high sequence similarity to bacterial CSP, which is up-regulated by cold and is capable of binding nucleic acids, were found in barley (Hordeum vulgare) [blt 801 (Dunn et al., 1996)] and winter wheat [WCSP1 (Karlson et al., 2002)]. Chaikam and Karlson (2008) showed that CSP in rice $(O S C S P)$ was more highly expressed in reproductive tissues and tissues with high meristematic activity. Similar to our study, Karlson et al. (2002) 
observed that the level of WCSP1 was low in NA plants, but then it was gradually increased during $18 \mathrm{~d}$ of cold acclimation.

SeCondary METABolism. One protein involved in secondary metabolism, the enzyme UDP-D-glucuronate decarboxylase (spot 13), was found to increase in abundance in response to A4. In response to A4 + SZA2, however, the abundance of UDP-D-glucuronate decarboxylase was lower than the abundance at A4 and did not differ from the non-acclimated control.

The enzyme UDP-D-glucuronate decarboxylase catalyzes conversion of UDP-D-glucuronate into UDP-D-xylose. In general, there is an increase in the activity of enzymes involving in the synthesis of polysaccharides entering the pectin matrix of cell wall during periods of cell division and cell elongation (Dalessandro and Northcote, 1977). Along with the plasma membrane, the cell wall serves as a barrier for the propagation of extracellular ice and maintains the cell integrity during desiccation caused by freezing (Yamada et al., 2002). Taken together, the increased abundance of UDP-D-glucuronate decarboxylase in our study may suggest changes in the composition of the cell wall matrix during cold acclimation and/or induced cell division for the purpose of reduction of cell size. However, additional research is necessary to understand how changes in cell wall mechanical behavior are related to acquisition of freezing tolerance.

In summary, acclimation of plants for 4 weeks at $2{ }^{\circ} \mathrm{C}$ significantly increased freezing tolerance in velvet bentgrass, whereas additional SZA did not provide additional freezing tolerance compared with prolonged cold acclimation at abovezero temperatures. The cold acclimation-induced freezing tolerance could be mainly associated the cold acclimation-responsive (up-regulated or down-regulated) proteins involved in amino acid metabolism, energy, stress defense, and secondary metabolism in velvet bentgrass. The expression pattern and specific biochemical functions involved in freezing tolerance for those cold acclimation-responsive proteins deserves further confirmation using Western blotting and additional molecular analyses.

\section{Literature Cited}

Aamlid, T.S., B. Molteberg, F. Enger, A.A. Steensohn, and A. Susort. 2006. Evaluation of Agrostis and Festuca varieties for use on Scandinavian golf greens. Results from variety testing at Landvik and Apelsvoll 2003-2006. Bioforsk Rpt. 1:1-32.

Alcázar, R., T. Altabella, F.M.C. Bortolotti, M.R.C. Koncz, P. Carrasco, and A.F. Tiburcio. 2010. Polyamines: Molecules with regulatory functions in plant abiotic stress tolerance. Planta 231:1237-1249.

Alcázar, R., J.C. Cuevas, J. Planas, X. Zarza, C. Bortolotti, P. Carrasco, J. Salinas, A.F. Tiburcio, and T. Altabella. 2011. Integration of polyamines in the cold acclimation response. Plant Sci. 180:31-38.

Ali, G.M. and S. Komatsu. 2006. Proteomic analysis of rice leaf sheath during drought stress. J. Proteome Res. 5:396-403.

Amme, S., A. Matros, B. Schlesier, and H.-P. Mock. 2006. Proteome analysis of cold stress response in Arabidopsis thaliana using DIGEtechnology. J. Expt. Bot. 57:1547-1551.

Baek, K.H. and D.Z. Skinner. 2003. Alteration of antioxidant enzyme gene expression during cold acclimation of near-isogenic wheat lines. Plant Sci. 165:1221-1227.

Balbuena, T.S., J.J. Salas, E. Martínez-Force, R. Garcés, and J.J. Thelen. 2011. Proteome analysis of cold acclimation in sunflower. J. Proteome Res. 10:2330-2346.

Bertrand, A., Y. Castonguay, A. Azaiez, T. Hsiand, and J. Dionne. 2011. Cold-induced responses in annual bluegrass genotypes with differential resistance to pink snow mold (Microdochium nivale). Plant Sci. 180:111-119.
Bertrand, A., Y. Castonguay, P. Nadeau, S. Laberge, R. Michaud, G. Belanger, and P. Rochette. 2003. Oxygen deficiency affects carbohydrate reserves in overwintering forage crops. J. Expt. Bot. 54:1721-1730.

Bevan, M., I. Bancroft, E. Bent, K. Love, H. Goodman, C. Dean, R. Bergkamp, W. Dirkse, M. Van Staveren, W. Stiekema, L. Drost, P. Ridley, S.-A. Hudson, K. Patel, G. Murphy, P. Piffanelli, H. Wedler, E. Wedler, R. Wambutt, T. Weitzenegger, T.M. Pohl, N. Terryn, J. Gielen, R. Villarroel, R. De Clerck, M. Van Montagu, A. Lecharny, S. Auborg, I. Gy, M. Kreis, N. Lao, T. Kavanagh, S. Hempel, P. Kotter, K.-D. Entian, M. Rieger, M. Schaeffer, B. Funk, S. MuellerAuer, M. Silvey, R. James, A. Montfort, A. Pons, P. Puigdomenech, A. Douka, E. Voukelatou, D. Milioni, P. Hatzopoulos, E. Piravandi, B. Obermaier, H. Hilbert, A. Düsterhöft, T. Moores, J.D.G. Jones, T. Eneva, K. Palme, V. Benes, S. Rechman, W. Ansorge, R. Cooke, C. Berger, M. Delseny, M. Voet, G. Volckaert, H.-W. Mewes, S. Klosterman, C. Schueller, and N. Chalwatzis. 1998. Analysis of $1.9 \mathrm{Mb}$ of contiguous sequence from chromosome 4 of Arabidopsis thaliana. Nature 391:485-488.

Bocian, A., A. Kosmala, M. Rapacz, B. Jurczyk, L. Marczak, and Z. Zwierzykowski. 2011. Differences in leaf proteome response to cold acclimation between Lolium perenne plants with distinct levels of frost tolerance. J. Plant Physiol. 168:1271-1279.

Bradford, M.M. 1976. A rapid and sensitive method for quantification of microgram quantities of protein utilizing the principle of proteindye-binding. Anal. Biochem. 72:248-254.

Brilman, L. 2003. Velvet bentgrass, p. 201-206. In: Casler, M.D. and R.R. Duncan (eds.). Turfgrass biology, genetics, and breeding. Wiley, Hoboken, NJ.

Byun, Y.J., H.J. Kim, and D.H. Lee. 2009. LongSAGE analysis of the early response to cold stress in arabidopsis leaf. Planta 229:11811200 .

Chaikam, V. and D. Karlson. 2008. Functional characterization of two cold shock domain proteins from Oryza sativa. Plant Cell Environ. 31:995-1006.

Chakraborty, N., T. Chang, M.D. Casler, and G. Jung. 2006. Response of bentgrass cultivars to Sclerotinia homoeocarpa isolates representing 10 vegetative compatibility groups. Crop Sci. 46:1237-1244.

Close, T.J. 1996. Dehydrins: Emergence of a biochemical role of a family of plant dehydration proteins. Physiol. Plant. 97:795-803.

Close, T.J., A.A. Kortt, and P.M. Chandler. 1989. A cDNA-based comparison of dehydration-induced proteins (dehydrins) in barley and corn. Plant Mol. Biol. 13:95-108.

Courtois-Verniquet, F. and R. Douce. 1993. Lack of aconitase in glyoxysomes and peroxisomes. Biochemistry 294:103-107.

DaCosta, M. and B. Huang. 2006. Minimum water requirements for creeping, colonial, and velvet bentgrasses under fairway conditions. Crop Sci. 46:81-89.

Dalessandro, G. and D.H. Northcote. 1977. Possible control sites of polysaccharide synthesis during cell growth and wall expansion of pea seedlings (Pisum sativum L.). Planta 134:39-44.

Dionne, J., Y. Castonguay, P. Nadeau, and Y. Desjardins. 2001a. Freezing tolerance and carbohydrate changes during cold acclimation of green-type annual bluegrass (Poa апnиa L.) ecotypes. Crop Sci. 41:443-451.

Dionne, J., Y. Castonguay, P. Nadeau, and Y. Desjardins. 2001b. Amino acid and protein changes during cold acclimation of green-type annual bluegrass (Poa annua L.) ecotypes. Crop Sci. 41:1862-1870.

Duman, J.G. and T.M. Olsen. 1993. Thermal hysteresis protein activity in bacteria, fungi and phylogenetically diverse plants. Cryobiology 30:322-328.

Dunn, M.A., K. Brown, R. Lightowlers, and M.A. Hughes. 1996. A low-temperature-responsive gene from barley encodes a protein with single-stranded nucleic acid-binding activity which is phosphorylated in vitro. Plant Mol. Biol. 30:947-959.

Ebdon, J.S., R.A. Gagne, and R.A. Manley. 2002. Comparative cold tolerance in diverse turf quality genotypes of perennial ryegrass. HortScience 37:826-830. 
Espevig, T., M. DaCosta, L. Hoffman, T.S. Aamlid, A.M. Tronsmo, B.B. Clarke, and B. Huang. 2011. Freezing tolerance and carbohydrate changes of two Agrostis species during cold acclimation. Crop Sci. 51:1188-1197.

Giavalisco, P., E. Nordhoff, T. Kreitler, K. Kloppel, H. Lehrach, J. Klose, and J. Gobom. 2005. Proteome analysis of Arabidopsis thaliana by two-dimensional gel electrophoresis and matrix-assisted laser desorption/ionization-time of flight mass spectrometry. Proteomics 5:1902-1913.

Griffith, M., M. Antikanen, W.C. Hon, K. Pihakaski-Maunsbach, X.M. Yu, J.U. Chun, and D.S.C. Yang. 1997. Antifreeze proteins in winter rye. Physiol. Plant. 100:327-332.

Griffith, M. and M.W.F. Yaish. 2004. Antifreeze proteins in overwintering plants: A tale of two activities. Trends Plant Sci. 9:399405.

Gusta, L.V., F.D. Butler, C. Rajashekar, and M.J. Burke. 1980. Freezing resistance of perennial turfgrasses. HortScience 15:494496.

Guy, C. 1999. Molecular responses of plants to cold shock and cold acclimation. J. Mol. Microbiol. Biotechnol. 1:231-242.

Hahn, M. and V. Walbot. 1989. Effects of cold-treatment on protein synthesis and mRNA levels in rice leaves. Plant Physiol. 91:930 938.

Herman, E.M., K. Rotter, R. Premakumar, G. Elwinger, R. Bae, L. Ehler-King, S. Chen, and D.P. Livingston. 2006. Additional freeze hardiness in wheat acquired by exposure to $-3{ }^{\circ} \mathrm{C}$ is associated with extensive physiological, morphological, and molecular changes. J. Expt. Bot. 57:3601-3618.

Hill, T. and P. Lewicki. 2007. STATISTICS methods and applications. StatSoft, Tulsa, OK.

Hoagland, D.R. and D.I. Arnon. 1950. The water-culture method for growing plants without soil. California Agr. Expt. Sta. Circ. 347:1-32. Hoffman, L., M. DaCosta, J.S. Ebdon, and E. Watkins. 2010. Physiological changes during cold acclimation of perennial ryegrass accessions differing in freeze tolerance. Crop Sci. 50:1037-1047.

Hulke, B.S., E. Watkins, D. Wyse, and N. Ehlke. 2008. Freezing tolerance of selected perennial ryegrass (Lolium perenne L.) accessions and its association with field winterhardiness and turf traits. Euphytica 163:131-141.

Humphreys, M.O. and C.F. Eagles. 1988. Assessment of perennial ryegrass (Lolium perenne L.) for breeding. I. Freezing tolerance. Euphytica 38:75-84.

Huner, N.P.A., G. Öquist, V.M. Hurry, M. Krol, S. Falk, and M. Griffith. 1993. Photosynthesis, photoinhibition and low temperature acclimation in cold tolerant plants. Photosynth. Res. 37:19-39.

Huner, N.P.A., G. Öquist, and F. Sarhan. 1998. Energy balance and acclimation to light and cold. Trends Plant Sci. 3:224-230.

Janská, A., P. Maršík, S. Zelenková, and J. Ovesná. 2010. Cold stress and acclimation-What is important for metabolic adjustment? Plant Biol. 12:395-405.

Karlson, D., K. Nakaminami, T. Toyomasu, and R. Imai. 2002. A coldregulated nucleic acid-binding protein of winter wheat shares a domain with bacterial cold shock proteins. J. Biol. Chem. 277:35248-35256.

Klimov, C.B. 2009. Winter hardiness of winter wheat depends on temporal adaptation of photosynthesis and respiration [in Russian]. Izvestia Rossiiskoi Akademii Nauk. Seriya Biologicheskaya 3:313322.

Kocsy, G., G. Galiba, and C. Brunold. 2001. Role of glutathione in adaptation and signalling during chilling and cold acclimation in plants. Physiol. Plant. 113:158-164.

Koeritz, E.J. and J.C. Stier. 2009. Nitrogen rate and mowing height effects on velvet and creeping bentgrasses for low-input putting greens. Crop Sci. 49:1463-1472.

Kosmala, A., A. Bocian, M. Rapacz, B. Jurczyk, and Z. Zwierzykowski. 2009. Identification of leaf proteins differentially accumulated during cold acclimation between Festuca pratensis plants with distinct levels of frost tolerance. J. Expt. Bot. 60:3595-3609.
Kramer, G.F. and C.Y. Wang. 1990. Effects of chilling and temperature preconditioning on the activity of polyamine biosynthesis enzymes in zucchini squash. J. Plant Physiol. 136:115-122.

Le, M.Q., W.R. Engelsberger, and D.K. Hincha. 2008. Natural genetic variation in acclimation capacity at sub-zero temperatures after cold acclimation at $4{ }^{\circ} \mathrm{C}$ in different Arabidopsis thaliana accessions. Cryobiology 57:104-112.

Livingston, D.P. 1991. Nonstructural carbohydrate accumulation in winter oat crowns before and during cold hardening. Crop Sci. 31:751-755.

Livingston, D.P. 1996. The second phase of cold hardening: Freezing tolerance and fructan isomer changes in winter cereals. Crop Sci. 36:1568-1573.

Machida, T., H. Murase, E. Kato, K. Honjoh, K. Matsumoto, T. Miyamoto, and M. Iio. 2008. Isolation of cDNAs for hardening-induced genes from Chlorella vulgaris by suppression subtractive hybridization. Plant Sci. 175:238-246.

Mittler, R., S. Vanderauwera, M. Gollery, and F. Van Breusegem. 2004. Reactive oxygen gene network of plants. Trends Plant Sci. 9:490-498.

Moeder, W., O. del Pozo, D.A. Navarre, G.B. Martin, and D.F. Klessig. 2007. Aconitase plays a role in regulating resistance to oxidative stress and cell death in arabidopsis and Nicotiana benthamiana. Plant Mol. Biol. 63:273-287.

Molteberg, B., T.S. Aamlid, F. Enger, A.A. Steensohn, and Å. Susort. 2008. Evaluation of Agrostis and Festuca varieties for use on Scandinavian golf greens, p. 137-138. In: Volterrani, M. (ed.). Proc. 1st European Turfgrass Soc. Conf., Pisa, Italy, 19-20 May 2008.

Naidu, B.P., L.G. Paleg, D. Aspinall, A.C. Jennings, and G.P. Jones. 1991. Amino acid and glycine betaine accumulation in cold-stressed wheat seedlings. Phytochemistry 30:407-409.

Neill, S.J., R. Desikan, A. Clarke, R.D. Hurst, and J.T. Hancock. 2002. Hydrogen peroxide and nitric oxide as signalling molecules in plants. J. Expt. Bot. 53:1237-1247.

Newsholme, S.J., B.F. Maleeft, S. Steiner, N.L. Anderson, and L.W. Schwartz. 2000. Two-dimensional electrophoresis of liver proteins: Characterization of a drug-induced hepatomegaly in rats. Electrophoresis 21:2122-2128.

Patton, A.J., S.M. Cunningham, J.J. Volenec, and Z.J. Reicher. 2007. Differences in freeze tolerance of zoysiagrasses: I. Role of proteins. Crop Sci. 47:2162-2169.

Perras, M. and F. Sarhan. 1989. Synthesis of freezing tolerance proteins in leaves, crown, and roots during cold acclimation in wheat. Plant Physiol. 89:577-585.

Puhakainen, T., M.W. Hess, P. Mäkelä, J. Svensson, P. Heino, and E.T. Palva. 2004. Overexpression of multiple dehydrin genes enhances tolerance to freezing stress in arabidopsis. Plant Mol. Biol. 54:743-753.

Rajashekar, C.B. 2006. Molecular responses and mechanisms of plant adaptation to cold and freezing stress, p. 47-68. In: Huang, B. (ed.). Plant-environment interactions. CRC Press, Boca Raton, FL.

Rapacz, M., B. Wolanin, K. Hura, and M. Tyrka. 2008. The effects of cold acclimation on photosynthetic apparatus and the expression of COR14b in four genotypes of barley (Hordeum vulgare) contrasting in their tolerance to freezing and high-light treatment in cold conditions. Ann. Bot. (Lond.) 101:689-699.

Ravanel, S., B. Gakière, D. Job, and R. Douce. 1998. The specific features of methionine biosynthesis and metabolism in plants. Proc. Natl. Acad. Sci. USA 95:7805-7812.

Renaut, J., S. Planchon, M. Oufir, J.F. Hausman, L. Hoffmann, and D. Evers. 2009. Identification of proteins from potato leaves submitted to chilling temperature, p. 279-292. In: Gusta, L.V., M.E. Wisniewski, and K.K. Tanino (eds.). Plant cold hardiness: From the laboratory to the field. CAB International, Wallingford, UK.

Rorat, T., W. Irzykowski, and W.J. Grygorowicz. 1997. Identification and expression of novel cold induced genes in potato (Solanum sogarandinum). Plant Sci. 124:69-78.

Sagisaka, S., Y. Matsuda, T. Okuda, and S. Ozeki. 1991. Relationship between wintering ability of winter wheat and the extent of depression 
of carbohydrate reserves: Basal metabolic rate under snow determines longevity of plants. Soil Sci. Plant Nutr. 37:531-541.

Sandve, S.R., H. Rudi, T. Asp, and O.A. Rognli. 2008. Tracking the evolution of a cold stress associated gene family in cold tolerant grasses. BMC Evol. Biol. 8:245.

Sarnighausen, E., V. Wurtz, D. Heintz, A.V. Dorsselaer, and R. Resk. 2004. Mapping of the Physcomitrella patens proteome. Phytochemistry 65:1589-1607.

Schirch, V. and D.M. Szebenyi. 2005. Serine hydroxymethyltransferase revisited. Curr. Opin. Chem. Biol. 9:482-487.

Sieg, F., W. Schröder, J.M. Schmitt, and D.K. Hincha. 1996. Purification and characterization of a cryoprotective protein (cryoprotectin) from the leaves of cold-acclimated cabbage. Plant Physiol. 111:215-221.

Steponkus, P.L. and D.V. Lynch. 1989. Freeze/thaw-induced destabilization of the plasma membrane and the effects of cold acclimation. J. Bioenerg. Biomembr. 21:21-41.

Tepperman, J.M., T. Zhu, H.-S. Chang, X. Wang, and P.H. Quail. 2001. Multiple transcription-factor genes are early targets for phytochrome A signaling. Proc. Natl. Acad. Sci. USA 98:94379442.

Thomashow, M.F. 1999. Plant cold acclimation: Freezing tolerance genes and regulatory mechanisms. Annu. Rev. Plant Physiol. Plant Mol. Biol. 50:571-599.

Tompkins, D.K., J.B. Ross, and D.L. Moroz. 2000. Dehardening of annual bluegrass and creeping bentgrass during late winter and early spring. Agron. J. 92:5-9.

Tronsmo, A.M., G. Kobro, S. Morgenlie, and R. Flengsrud. 1993. Carbohydrate content and glycosidase activities following cold hardening in two grass species. Physiol. Plant. 88:689-695.
Tumanov, I.I. 1940. Physiological fundamentals of winterhardiness of cultivated plants [in Russian]. Selhozizdat, Moskva, Leningrad, Russia.

Vágújfalvi, A., I. Kerepesi, G. Galiba, T. Tischner, and J. Sutka. 1999. Frost hardiness depending on carbohydrate changes during cold acclimation in wheat. Plant Sci. 144:85-92.

Veisz, O. and J. Sutka. 1989. The relationships of hardening period and the expression of frost resistance in chromosome substitution lines of wheat. Euphytica 43:41-45.

Verniquet, F., J. Gaillard, M. Neuburger, and R. Douce. 1991. Rapid inactivation of plant aconitase by hydrogen peroxide. Biochem. J. 276:643-648.

Volenec, J.J., A. Ourry, and B.C. Joern. 1996. A role for nitrogen reserves in forage regrowth and the stress tolerance. Physiol. Plant. 97:185-193.

Wang, K.L.C., L. Hi, and J.R. Ecker. 2002. Ethylene biosynthesis and signaling networks. Plant Cell 14:131-151.

Xiong, Y. and S.-Z. Fei. 2006. Functional and phylogenetic analysis of a DREB/CBF-like gene in perennial ryegrass (Lolium perenne L.). Planta 224:878-888.

$\mathrm{Xu}, \mathrm{C}$, Y. Xu, and B. Huang. 2008. Protein extraction for twodimensional gel electrophoresis of proteomic profiling in turfgrass. Crop Sci. 48:1-7.

Yamada, T., K. Kuroda, Y. Jitsuyama, D. Takezawa, K. Arakawa, and S. Fujikawa. 2002. Roles of the plasma membrane and the cell wall in the responses of plant cells to freezing. Planta 251:770-778.

$\mathrm{Yu}$, X.M., M. Griffith, and S.B. Wiseman. 2001. Ethylene induces antifreeze activity in winter rye leaves. Plant Physiol. 126:1232-1240.

Zhang, C., S.-Z. Fei, R. Arora, and D.J. Hannapel. 2010. Ice recrystallization inhibition proteins of perennial ryegrass enhance freezing tolerance. Planta 232:155-164. 